\title{
ANALYSIS OF THE EFFECT OF ISLAMIC BANK INCOME AND INCOME CONVENTIONAL BANKS AGAINST BANK PROFITABILITY
}

\author{
Muhammad Erwin SP 1 , Saparuddin Siregar ${ }^{2}$, Sugianto $^{3}$ \\ ${ }^{1}$ Institut Agama Islam EHMRI \\ ${ }^{2.3}$ Universitas Islam Negeri Sumatera Utara \\ E-mail: ${ }^{1)}$ muhammaderwin932@gmail.com,${ }^{2)}$ fsaparuddin.siregar@uinsu.ac.id, \\ ${ }^{3)}$ saparuddin.siregar@uinsu.ac.id
}

\begin{abstract}
Bank Syariah Indonesia has sharia contracts that can make it easier for customers to get consumptive financing such as financing in the purchase of cars/motorcycles, but many people do not know that Islamic banks have such consumptive financing products. Based on the results of research on the mechanism and application of consumptive financing on the Oto $i B$ Hasanah BNI Syariah Banda Aceh product, this can be done in three stages, namely: First, the customer applies for consumptive financing for the Oto iB Hasanah BNI Syariah Banda Aceh product by completing the file, second, checking data or verifying data for completeness and the truth of the file, thirdly, a field survey with the 5C principle (Character, Capacity, Capital, Condition and Collateral). murabahah namely an agreement on profit, payment method, sale and purchase agreement and delivery of goods.
\end{abstract}

\section{Keywords: Bank Income, Islamic Bank, Profitability}

\section{INTRODUCTION}

The banking industry in Indonesia has a very important role in the economy. Bank is one of the financial institutions that have an important role in the economy of a country as a financial intermediary institution. This is because banking is one of the financial systems that functions as a Financial Intermediary, which is an institution that has a role to bring together owners and users of funds. Therefore, bank activities must run efficiently on a macro and micro scale. Funds resulting from community mobility are allocated to various economic sectors and all areas in need, accurately and quickly.

To increase the mobilization of public funds that have not been served by the conventional banking system and to accommodate the need for banking services that are in accordance with sharia principles, in 1992 Islamic banks were officially introduced to the public.

From 1992 to 1998, there was only one Sharia Commercial Bank and 78 Sharia Rural Banks (BPRS) that had been operating. In 1998, Law no. 10 of 1998 concerning amendments to Law no. 7 of 1992 concerning banking. The law also provides directions for conventional banks to open sharia branches or even convert themselves to become fully Islamic banks (Novita Wulandari and Kiki Maharani: 2010).

At the end of 1999, along with the enactment of the banking law, commercial Islamic banks were established and commercial banks opened sharia business units. Since the operation of Bank Muamalat Indonesia (BMI), as the first Islamic bank in 1992, with one service office with initial assets of around Rp. 100 billion, then Bank Indonesia data as of June 30, 2011 shows that currently national Islamic banking has grown rapidly, when the perpetrators consisted of 11 Sharia Commercial Banks (BUS), 23 Sharia Business Units (UUS), and 154 Sharia Rural Banks (Statistics Indonesian Banking June 2011).

The development of Islamic commercial banks and conventional banks that opened sharia branches was also supported by the persistence of Islamic banks when the national banking crisis experienced a severe crisis in 1998 and the global crisis in 2008. The sharia banking profit sharing 
system implemented in Bank Muamalat products caused the bank relatively maintains its performance and is not carried away by soaring deposit interest rates so that operating expenses are lower than conventional banks (Ema Rindawati: 2007).

\section{THEORETICAL FRAMEWORK}

\subsection{Conventional Bank}

The interest system carried out by conventional banks has several principles, namely:

1. Determination of interest rates is made at the time of the contract with the guidelines that it must always be profitable for the parties Bank .

2. The percentage is based on the amount of money (capital) lent. Interest rate determination is made at the time of the contract with the guidelines that it must always be profitable for the Bank.

3. The amount of interest payments is not binding even though the amount of profit doubles when economic conditions are good.

4. The existence of halal flowers is doubted by all religions, including Islam.

5. Fixed interest payments as promised without considering the project carried out by the customer, profit or loss.

\subsection{Sharia Banks and their Operational Principles}

The basic principles of Islamic banking are based on the Quran and Sunnah. After a deeper study, the basic philosophy of the operation of Islamic banks that animates all transaction relationships is based on three principles, namely efficiency, justice, and togetherness. Efficiency refers to the principle of helping each other in a synergistic manner to obtain the largest possible profit/margin. Fairness refers to a relationship that is not rigged, sincere, with mature agreement on the proportion of inputs and outputs. Togetherness refers to the principle of offering mutual assistance and advice to increase productivity (Edy Wibowo: 2014).

In carrying out its activities, Islamic banks adhere to 3 (three) main principles:

1. The principle of justice, this principle is reflected in the application of rewards on the basis of profit sharing and profit margins that are mutually agreed upon between the bank and the customer.

2. The principle of equality, Islamic banks place depositors of funds, customers who use funds, and banks in the same and equal positions. This is reflected in the rights, obligations, risks and benefits that are balanced between depositors, customers who use funds and banks.

3. The principle of peace, Islamic bank products are in accordance with the principles and rules of Islamic mu'amalah (halal), including the element of usury and applying zakat on assets. Thus, customers feel inner and outer peace.

Based on the 3 (three) main principles for Islamic banks mentioned above, in the operational activities of services to the public, Islamic banks apply the basic principles of Islamic banking. These basic principles are:

\section{Trust Principle (Depository/Al Wadi'ah)}

The principle of deposit or savings in the Islamic fiqh tradition is known as the Al Wadi'ah principle. Al Wadi'ah can be interpreted as a pure deposit from one party to another, both individuals and legal entities, which must be guarded and returned whenever the custodian wishes. Wadi'ah contract is a contract that is mutual help between human beings. Wadi'ah which is practiced in Islamic banks in Indonesia is wadi'ah in the sense of pure deposit which with the permission of the custodian may be used by the bank, so the concept of wadi'ah used is wadi'ah yad ad daminah (deposit with the risk of compensation). make a loss). 


\section{Profit Sharing Principle (Profit Sharing/Al Musyarakah \& Al Mudharabah)}

In general, the principle of profit sharing in Islamic banking can be carried out in 4 (four) main contracts, namely: al musyarakah, al mudharabah, al muzara'ah and al musaqah. Even so, the most widely used principles are al musharaka and al mudharabah, while al muzara'ah and al musaqah are used specifically for agricultural financing (plantation financing) by several Islamic banks.

Musyarakah is a cooperation agreement between two or more parties for a particular business in which each party contributes funds (charity/expertise) with the agreement that the profits and risks will be shared in accordance with the agreement. Meanwhile, al mudharabah is a business cooperation agreement between two parties where the first party (shahibul maal) provides all the capital (100\%), while the other party becomes the manager.

\section{The Principle of Buying and Selling (Sale and Purchase/Bai' Al Murabahah)}

The forms of sale and purchase contracts that are often used in financing working capital and investment in Islamic banking are bai' al murabahah, bai' as salam and bai' al istishna. Murabaha is the sale and purchase of goods at the original price with an agreed additional profit. This financing system is basically financing with a buying and selling system, where the bank finances the purchase of goods to the customer in the amount of the cost of goods plus the profit margin agreed between the bank and the customer. While the meaning of bai' as salam is the purchase of goods to be delivered at a later date with payment made in advance.

\section{Lease Principle (Lease/Al Ijarah)}

The principle of lease (al ijarah) is a contract for the transfer of usufructuary rights over goods or services, through payment of rental wages, without being followed by a transfer of ownership of the goods themselves. Islamic banks that offer al ijarah products can do leasing, both in the form of operating leases and financial leases. In addition to the four basic principles in Islamic banking as described above.

\section{Service Principle (Fee Based Services)}

There is one more basic principle, namely the service principle. Included in this service group are several Islamic bank products, namely al wakalah, al kafalah, al hawalah, arrahn and al qardh. The service principle in Islamic banking is a principle that is supportive and complementary to other basic principles, because in this service group it is usually used as an additional contract that is guarantee/ guarantee for other products/contracts.

\section{Profit Sharing}

One method of profit sharing is profit sharing (Profit Sharing) namely profit sharing which is calculated from income after deducting the cost of managing funds. In the sharia system, it can be used for distribution of business results of Islamic financial institutions If a sharia bank applies the distribution of operating results based on the principle of profit sharing, the sharia bank must make two separate profit and loss statements, namely the profit and loss statement of the bank as a sharia financial institution and a report on the management of mudharabah funds where the bank is the mudharib.

Some things to note are:

a. Bank income as mudharib. The income in this report is the share of income from the management of mudharabah funds obtained by Islamic banks and distribution income which belongs to the Islamic banks themselves.

b. Operating income is the same income as other operating income in the profit sharing principle. 
c. Operating expenses are expenses incurred by Islamic banks as Islamic financial institutions themselves that have nothing to do with the management of mudharabah funds, both labor costs, general and administrative expenses and other expenses.

\section{Financing}

In a narrow sense, financing is used to define funding made by financing institutions such as Islamic banks to customers. Meanwhile, according to M. Syafie I Antonio, explaining that financing is one of the main tasks of banks, namely providing fund facilities to meet the needs of parties who are deficit units. According to the Banking Law No. 10 of 1998, it is the provision of money or an equivalent claim, based on an agreement or agreement between the bank and another party that obliges the party who is financed to return the money or claim after a certain period of time with compensation or profit sharing. Financing is the provision of money or claims based on an agreement between the bank and other parties who are required to return the money or claims after a certain period of time with compensation or profit sharing. (Ahmad Rivai: 2011). Financing at this bank has differences in the distribution of capital and business management, as well as profit sharing. profit-sharing banks provide profits to depositors with the Financing to Deposit Rate (FDR) approach, while conventional banks use a fee approach. Below is a table about the net profit of BRI Syariah banks and conventional BRI Banks while conventional banks approach the cost. Below is a table about the net profit of BRI Syariah banks and conventional BRI Banks while conventional banks approach the cost. Below is a table about the net profit of BRI Syariah banks and conventional BRI Banks.

Table 1. BRI Syariah Bank Financial Report Data (In IDR Millions)

\begin{tabular}{|c|c|c|c|}
\hline No. & Year & Financing & Net profit \\
\hline 1 & 2012 & $1,046,197$ & 35,657 \\
\hline 2 & 2013 & $2,600,172$ & 16,216 \\
\hline 3 & 2014 & $5,527,081$ & 10,954 \\
\hline 4 & 2015 & $9,170,300$ & 11,654 \\
\hline 5 & 2016 & $11,403,000$ & 101.888 \\
\hline
\end{tabular}

Data Source: BRISyariah.co.id

From the data above, we can see that the financing carried out by BRI Syariah Bank in 2012 was BRI Syariah bank financing of Rp. 1,046,197 million and earned a net profit of Rp. 35,657 million, and so on in 2013 Bank BRI Syariah financing was Rp. 2,600,172 million and profit net Rp. 16,216 million, at In 2014 the financing carried out by BRI Syariah was Rp.5,527,081 million and the net profit was Rp. 10,954 million, the following year 2015 the financing by the BRI Syariah bank was Rp.9,170,300 million and the net profit was Rp. 11,654 million, and in 2016 the financing by the BRI Syariah bank was Rp.11 .403,000 million and a net profit of Rp101,888 million.

Table 2. BRI Bank Financial Report Data (In IDR Billion)

\begin{tabular}{|c|c|c|c|}
\hline No. & Year & Financing & Net profit \\
\hline 1 & 2012 & 73,538 & 5,958 \\
\hline 2 & 2013 & 101.371 & 7.308 \\
\hline 3 & 2014 & 130,298 & 11.472 \\
\hline 4 & 2015 & 153.353 & 15,088 \\
\hline 5 & 2016 & 185,726 & 18,687 \\
\hline
\end{tabular}

Data Source: BRI.co.id

From the data above, we can see that the financing and net profit carried out by BRI General banks from 2012 to 2016 namely in 2012 General BRI Bank Rp. 371 billion and a net profit of 
Rp7,308 billion, in 2014 the financing by Bank BRI Umum was Rp130,298 billion and a net profit of Rp11.47 billion, the following year 2015 the financing by Bank BRI Umum was Rp153,353 billion and the net profit was Rp15. 088 billion and in 2016 financing by BRI General bank was Rp185,726 billion and net profit was Rp18,687 billion.

From the data above, we can conclude that the financing carried out by BRI Syariah banks and Conventional BRI Banks continues to increase every year however, the net profit received by BRI Syariah banks does not always increase with increasing financing, but conventional BRI Bank net income received continues to increase along with the increase in financing. which is conducted. Fund management carried out by financial institutions must be carried out with full accuracy. This is intended so that the process of managing funds by the manager (borrower) can be well controlled and also to minimize the occurrence of losses such as bad loans. Thus, a financial institution must have three important aspects in financing, namely safe, smooth and profitable (Muhammad Ridwan: 2016).

a. Safe, namely the belief that funds that have been thrown into the community can be withdrawn in accordance with the agreed time period.

b. Smooth, namely the belief that the funds can be rotated by financial institutions smoothly and quickly.

c. Profitable, i.e. accurate calculations and projections.

8. Profitability

a. ROA (Return On Assets)

Profitability is the company's ability to earn profits by using a certain amount of capital (Ferdiansyah: 2007). Profitability or the ability to earn a profit is a measure in percentage used to assess the extent to which the company is able to generate profits. The greater the ROA of a bank, the greater the level of profit achieved by the bank, and the better the position of the bank in terms of asset use. (Dendawijaya: 2009). ROA is formulated as follows:

$$
\mathrm{ROA}=\frac{\text { Profit before tax }}{\text { Total assets }} \times 100 \%
$$

The profitability ratios used are as follows. Return on Assets (ROA), measured by net income before tax divided by total assets owned.

b. ROE (Return On Equity)

Return On Equity (ROE) is measured by net profit after tax divided by bank capital/equity. Total operating expenses divided by total operating income.

Return on equity (ROE) is the total return on net income on equity and is expressed as a percent. ROE is used to measure the ability of an issuer to generate profits by capitalizing on equity that has been invested by shareholders. ROE is expressed as a percentage and is calculated by the formula:

$$
\mathrm{ROE}=\frac{\text { Profit before tax }}{\text { equity }} \times 100 \%
$$

c. FDR (Financing To Deposit Ratio)

Financing To Deposit Ratio (FDR) is how far the bank's ability to repay the withdrawal of funds made by depositors with rely on the financing provided as a source of liquidity. The greater the financing, the income earned increases, because income increases automatically profits will also increase (Rahmawaty and Yudina: 2015). 


\section{PREVIOUS RESEARCH WRITING}

To avoid writing on the same object or repetition of the same research, as well as avoiding the assumption of plagiarism in certain works, it is necessary to review existing studies. Here are some articles related to this theme:

Table 3. Previous Research

\begin{tabular}{|c|l|c|l|}
\hline No. & \multicolumn{1}{|c|}{ Writer's name } & Year & \multicolumn{1}{|c|}{} \\
\hline 1 & $\begin{array}{l}\text { Muhammad Rizal } \\
\text { Aditya }\end{array}$ & 2016 & $\begin{array}{l}\text { The research Mudharabah Financing and Musyarakah } \\
\text { Financing on Profitability Levels of Islamic Commercial } \\
\text { Banks". The results of his research show that mudharabah } \\
\text { financing and musyarakah financing have a positive and } \\
\text { significan effect on the profitability level of Islamic } \\
\text { Commercial Banks for the 2010-2014 period. which title } \\
\text { "Influence. }\end{array}$ \\
\hline 2 & $\begin{array}{l}\text { Indriani Laela } \\
\text { Qodriasari }\end{array}$ & 2014 & $\begin{array}{l}\text { his research entitled "Analysis of the Effect of Mudharabah } \\
\text { Financing Income, Musyarakah, Murabahah, and Ijarah Leases } \\
\text { on the Profitability of Islamic Commercial Banks in Indonesia } \\
\text { ". The results showed that of the six banks studied, there was no } \\
\text { superior or prominent product in this case the income from } \\
\text { mudharabah, musyarakah, murabahah, and ijarah financing. }\end{array}$ \\
\hline 3 & $\begin{array}{l}\text { Ela Khalifah and } \\
\text { Amirus Sodiq }\end{array}$ & $\begin{array}{l}\text { "Influence Musyarakah on Profitability (Roa) of Bank Syariah } \\
\text { Mandiri Period 2006-2014". The results showed that the results } \\
\text { of the partial significance test data processing (t-test) obtained } \\
\text { that the Mudharabah income variable (X1) had a positive and } \\
\text { significant effect on the dependent variable (RoA). Income } \\
\text { Mudharabah And. }\end{array}$ \\
\hline
\end{tabular}

\subsection{Theoretical Framework}

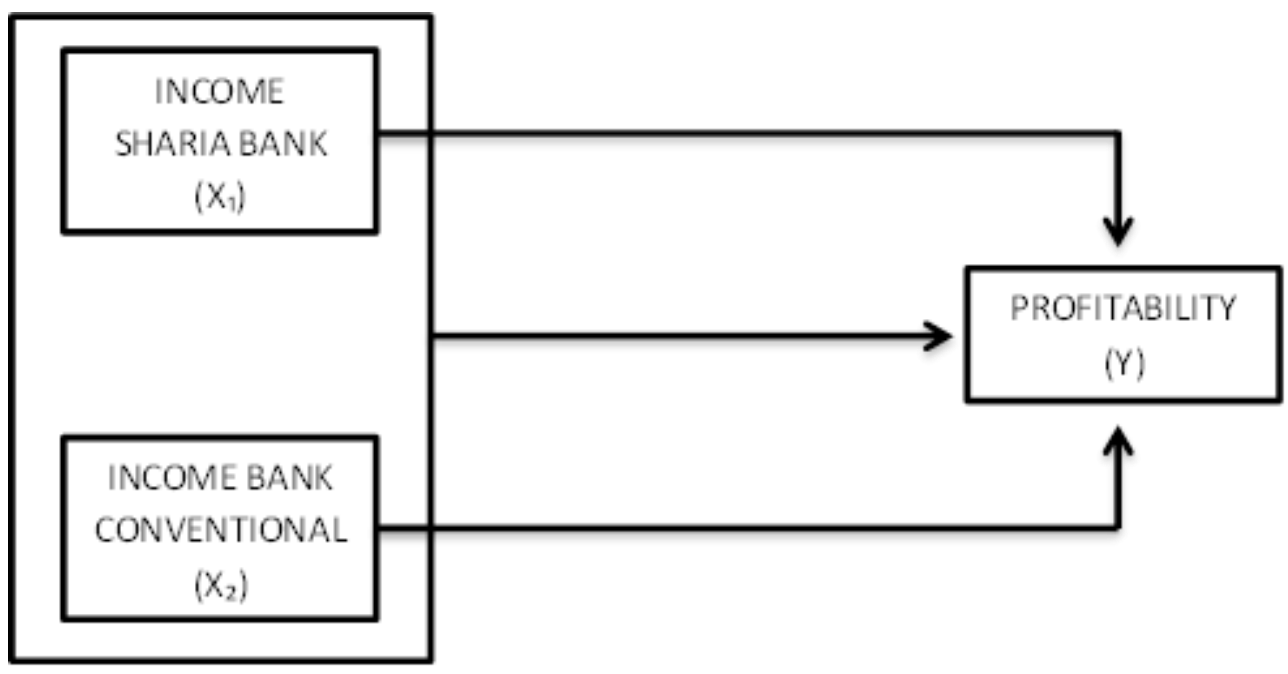

Figure 1. Theoretical Framework

\subsection{Hypothesis}

So the hypothesis in this study is as follows:

H: Allegedly the Concept of Islamic Bank Income Affects Bank Profitability

H: Allegedly Concept of Conventional Bank Income Against Bank Profitability

$\mathrm{H}$ : Allegedly the Concept of Islamic Bank Income and Conventional Bank Income simultaneous effect on Bank Profitability. 


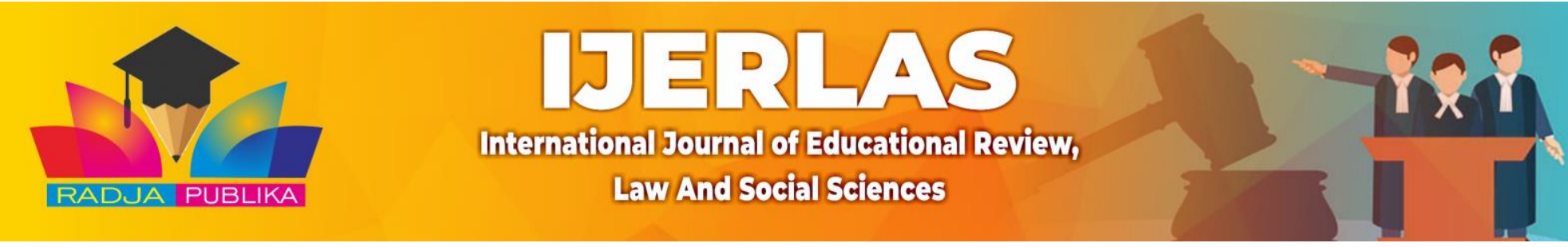

\subsection{Variable Operations}

The operational definition of a variable is a variable to be measured. The operational variables in this study are three variables, namely two independent variables (independent variable) and one dependent variable (dependent variable) which describes a causal relationship.

The operational definitions of variables in the research that the authors set in this study are based on the conceptual framework that has been stated in this study:

1. Islamic Bank Income (Independent variable), one of the profit sharing methods is Profit Sharing, namely profit sharing which is calculated from income after deducting fund management costs.

2. Conventional Bank income (Independent variable) is income minus all expenses/costs that have been incurred.

3. Profitability (Dependent variable) is the company's ability earn a profit, the unit used is the percentage (\%).

\section{IMPLEMENTATION METHOD}

To test the effect of Islamic bank income and conventional bank income on bank profitability, to prove the hypothesis, multiple linear regression with the help of Eviews is used.

The form of a simple linear regression formula is:

Where :

$$
\operatorname{Ln}(\mathbf{Y})=\mathbf{a}+\ln (\mathbf{X})+\ln (\mathbf{X})+\mathbf{e i}
$$

$\mathrm{X}=$ Islamic Bank Income

$\mathrm{X}=$ Conventional Bank Income $=$ Constant $=$ Bank profitability $\beta=$ Regression coefficient

$\mathrm{ei}=$ error term

\subsection{Classical Assumption Test \\ 4.1.1 Normality Test}

Normality test is a test carried out to determine whether the distribution of a data follows or approaches the normal distribution, namely the distribution of data with a bell shaped. Good data is data that has a pattern like a normal distribution, i.e. the distribution of the data does not deviate to the right and to the left.

\subsubsection{Autocorrelation Test}

Autocorrelation is the relationship between nuisance errors that appear in time series data (time series). The estimation of the linear regression model contains the assumption that there is no autocorrelation between the confounding errors. Autocorrelation test can be done by calculatingdurbinwetson (d), with compare the value of d against $\mathrm{dl}$ and du. After calculating the statistical value, it is then compared from the table with a significant level of 5\%. According to Ghozali (2013), there are 5 autocorrelation decisions that can be seen in the following table:

Table 4. Autocorrelation Decision Making

\begin{tabular}{|c|c|c|}
\hline Null Hypothesis & Decision & Fish \\
\hline There is a positive autocorrelation & Reject Ho & $1<\mathrm{dl}$ \\
\hline There is no positive autocorrelation & No decision & $-\mathrm{dl}<\mathrm{d}<4$ \\
\hline There is a negative autocorrelation & Reject Ho & $-\mathrm{du} \mathrm{d} 4-\mathrm{dl}$ \\
\hline There is no negative autocorrelation & No decision & $\mathrm{u}<\mathrm{d}<4-\mathrm{du}$ \\
\hline There is no positive or negative autocorrelation & Reject Ho & .
\end{tabular}

Source: (Ghozali, 2013)

\subsubsection{Heteroscedasticity Test}

The heteroscedasticity test aims to test whether in the regression model there is an inequality of variance from the residuals of one observation to another observation (Ghozali: 2013). 


\subsubsection{Multicollinearity Test}

This test aims to test a model whether there is a correlation between the independent variables in the regression model. This linear relationship between independent variables is called multicollinearity. A good regression model should not have a correlation between independent variables. If the independent variables are correlated with each other, then these variables are not orthogonal.

\subsection{Hypothesis Testing}

\subsubsection{T test (Partial Test)}

The test equipment is used to accept or reject the statistical hypothesis t, provided that: if i $\mathrm{g}$ $>\mathrm{e}$ at $0.05(5 \%)$. So 0 rejected and $\mathrm{H}$ accepted means that it is suspected that Islamic Bank Income and Conventional Bank Income have an effect on Bank Profitability. And if otherwise So 0 acceptedand rejected, meaning that it is suspected that Islamic Bank Financing and Conventional Bank Financing have no Effect on Bank Profitability.

\subsubsection{Simultaneous Test $(\mathrm{F})$}

In this study, to determine the significant level of influence of the independent variables together or simultaneously on the dependent variable, the $\mathrm{F}$ test was carried out by comparing the calculated $\mathrm{F}$ with the $\mathrm{F}$ table.

\subsubsection{Correlation Coefficient $(R)$}

The correlation coefficient aims to determine whether or not there is a strong relationship between variable $\mathrm{X}$ and Variable $\mathrm{Y}$. The correlation coefficient is given the symbol $r$. The value of this correlation coefficient is the smallest -1 and the largest +1 . (Ghozali, 2013).

\subsubsection{Coefficient of Determination $\left(R^{2}\right)$}

Aims to find out how far the variation of the independent variable can explain well the variation of the dependent variable. The coefficient of determination $\left(\mathrm{R}^{2}\right)$ is a number that gives the proportion or percentage of total variation in the dependent variable (Y) which is explained by the independent variable (X) (Ghozali: 2013).

\section{RESULTS AND DISCUSSION Bank Profitability Ratio}

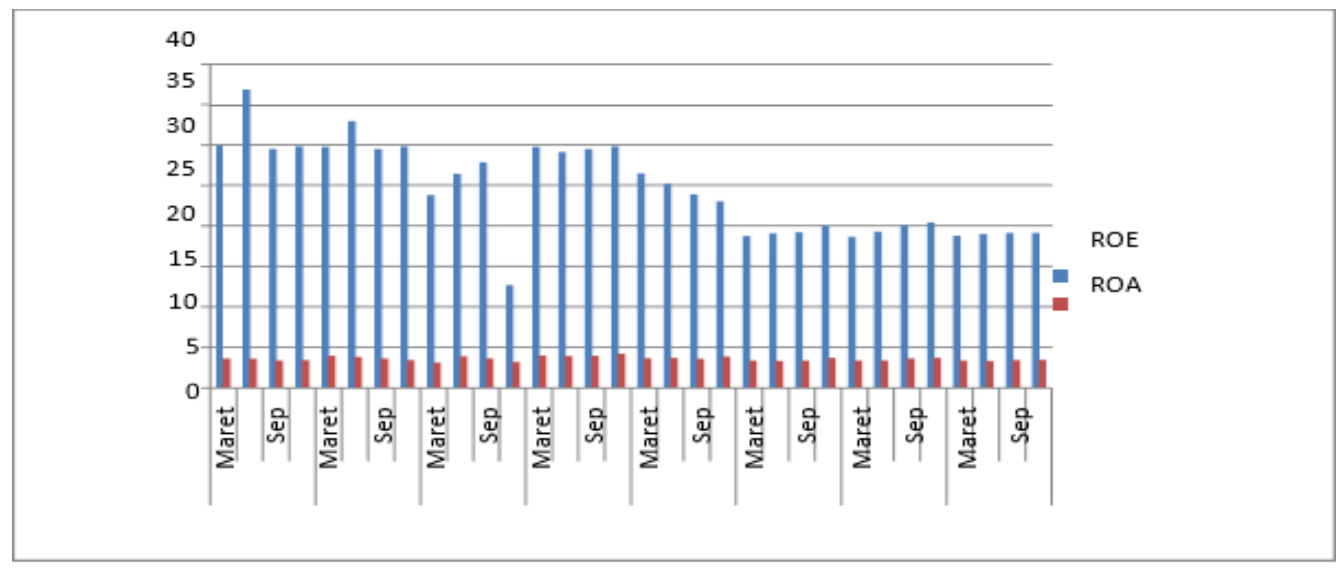

Sumber: Hasil Penelitian, 2020 (data diolah)

Figure 2. Data on ROA and ROE of Bank BRI in percent quarter 2012-2019 
Based on Figure 4.2 above, it can be explained that the profitability of BRI bank from from 2012 to 2019 in the quarterly period, namely the percent ROE is higher than ROA and changes every quarter.

\subsection{Normality Test}

The normality test aims to test whether in the regression model, the confounding or residual variables have a normal distribution or not by using the method Jarque-Bera (JB) Test to find out whether the regression model is normal or not. By comparing the value of $\mathrm{JB}$ count with the value of $\mathrm{X}_{2}$ (Chi-Square) table. If the value of $\mathrm{JB}$ count $>$ value $\mathrm{X}_{2}($ ChiSquare) table, then the residual value is not normally distributed and if the value of JB count < value $\mathrm{X}_{2}$ (Chi-Square) table, then the residual value is normally distributed.

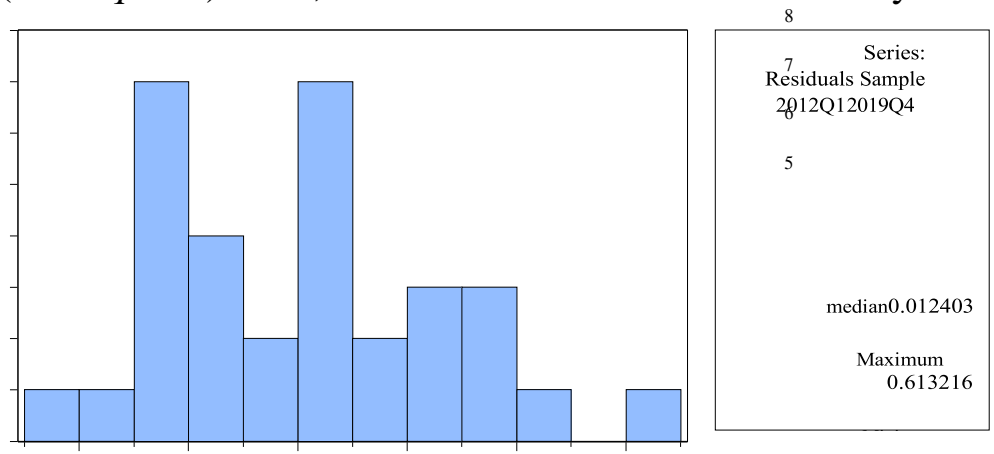

Figure 3. Normality Test

To find out the normal or abnormality of the residual data in the regression model, the confounding variable or residual, by comparing the calculated $\mathrm{JB}$ value with the $\mathrm{X}_{2}$ table. MarkX $\mathrm{X}_{2}$ table with $\mathrm{df}(3)=7.81$. When compared with the JB value in the table above of $1.05<7.81$, it can be concluded that the regression model, confounding variables or residuals in the model are normally distributed. This can also be seen from the probability (P-value) of $0.58>0.05$.

Table 5. Autocorrelation Test Results

Breusch-Godfrey Serial Correlation LM Test:

\begin{tabular}{|l|l|l|l|}
\hline statistics & 5193 & b. F(2.27) & 0.3900 \\
\hline bs*R-squared & 5839 & b. Chi-Square(2) & 0.3403 \\
\hline
\end{tabular}

Source: Research Results, 2020 (data processed)

Pay attention to the Prob Chi Square value which is the $\mathrm{p}$ value of the Breusch-Godfrey Serial Correlation LM test, which is 0.3403 where $>0.05$ so that it means there is no serial autocorrelation problem.

\subsection{Heteroscedasticity}

Heteroscedasticity test aims to determine whether in the regression model there is an inequality of variance from the residual of one observation to another observation. If the residual variance from one observation to another observation remains, it is called homoscedasticity, and if it is different it is called heteroscedasticity. How to detect whether or not this heteroscedasticity occurs in a regression model is by usingobs* $\mathrm{R}$-Squared compared with $\mathrm{X}_{2}$ table by using test white Heteroskedasticy. 


Oskedasticity Test: White
\begin{tabular}{|l|ll|r|}
\hline tistic & 971 & Prob. F $(4,27)$ & 0.6112 \\
\hline R-squared & 466 & Prob. Chi-Square(4) & 0.5692 \\
\hline d explained SS & 704 & Prob. Chi-Square(4) & 0.7855 \\
\hline
\end{tabular}

Source: Research Results, 2020 (data processed)

Based on Table 4.2 above, it shows that the data model used in this study is free from heteroscedasticity, from these results it can be seen from obs*R- Squared $<X_{2}$ table on $\operatorname{df}(2)=2.93$, so $4.55<7.81$. This can also be seen from the value ofprobability (P-value) of $0.78>0.05$.

\subsection{Multicollinearity}

The multicollinearity test is intended to determine whether there is a perfect intercorrelation between several independent variables used in the regression equation. To see whether there is multicollinearity, it can be seen from the correlation coefficient of each independent variable where each independent variable does not have a correlation coefficient greater than 0.8 then the model is free from multicollinearity.

Table 7. Multicollinearity Test

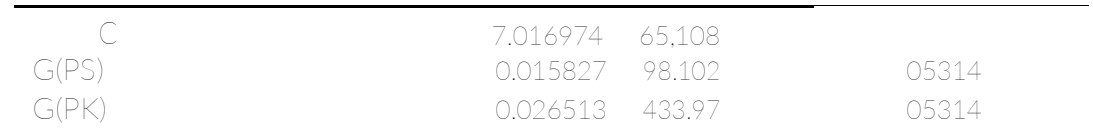

Source: Research Results, 2020 (data processed)

Based on the table above, above shows that the value of Centered VIF is good X and X is 4.305 where the value is less than 10 , it can be stated that there is no multicollinearity problem in the prediction model.

\section{Multiple Linear Regression Results}

In this study using multiple log-linear regression analysis which serves to determine whether there is an influence between the variables of Islamic bank income and conventional bank income on bank profitability with the regression equation: $\ln ()=0+{ }_{1}\left(X_{1)}+{ }_{2}\left(X_{2}\right)+\right.$ ei. To see the results of the estimation of the research model data processed with the help of the Eviews 9 program, the results of the regression analysis calculations are obtained as shown in Figure 4.1 below:

Table 8. Multiple Log-linear Regression Analysis Results

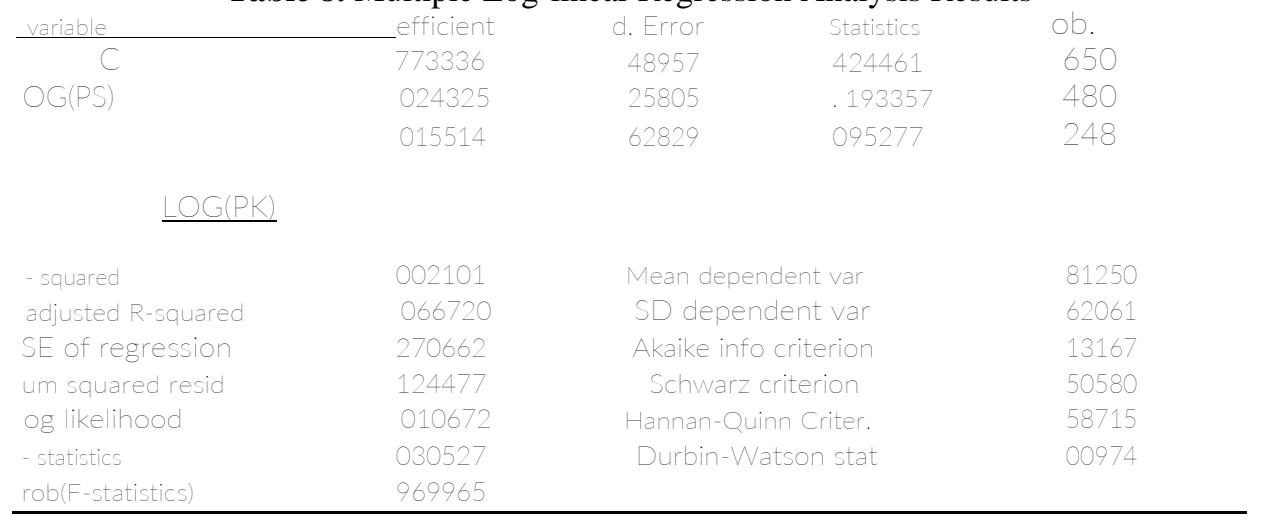

Source: Research Results, 2020 (data processed) 
Based on the results of the analysis of the regression model in table 4.4, it can be arranged into a mathematical equation as follows:

$$
\operatorname{Ln}(Y)=3.773-0.024\left(X_{1}\right)+0.015\left(X_{2)}+e\right.
$$

The constant value of 3.773 means that if the income variable of Islamic banks and conventional bank income is considered constant, then the profitability variable will also be constant at $3.773 \%$. The regression coefficient value of Islamic bank income is -0.024 shows a negative relationship which means that if the Islamic bank income variable increases by $1 \%$ it will decrease the profitability variable by $-0.024 \%$ assuming that the conventional bank income variable is considered constant.

The coefficient value of the amount of conventional bank income of 0.015 indicates a positive relationship which means that if the variable amount of conventional bank income increases by $1 \%$, it will increase the profitability variable by $0.015 \%$ with the assumption that the Islamic bank income variable is considered constant.

\section{Coefficient of Determination and Correlation Coefficient $(\mathbf{R})$ a. Coefficient of Determination}

The coefficient of determination in linear regression is often defined as how much influence all independent variables have in explaining the variance of the dependent variable. In simple terms the coefficient of determination is calculated by squaring the correlation coefficient $(R)$. Then the value of the coefficient of determination ( 2 ) of 0.06 which means that there is an influence between the independent variable and the dependent variable, changes that occur in the dependent variable can be explained by the independent variable of $0.06(6 \%)$, while that which is influenced by other variables outside this multiple linear regression model is $1-0.06=0.94(94 \%)$.

\section{b. Correlation Coefficient (R)}

The correlation coefficient is the magnitude of the relationship between one variable and another variable expressed by the correlation coefficient. The value of the correlation coefficient is $=_{2}=0.06=0.2450(24.50 \%)$ which shows that the relationship between Islamic bank income variables and conventional bank income on bank profitability has a small positive relationship because the correlation value is 0.2450 or below $50 \%$.

\section{Analysis results}

\section{a. The Effect of Islamic Bank Income (X) Against Bank Profitability (Y)}

The partial effect was carried out using t-test statistics. This test aims to determine whether the independent variables included in the model are able to explain the dependent variable individually. The test results can be seen in Table 1. The t-test was carried out to determine whether there was a partial effect of the independent variable on the dependent variable statistically. The test used is provided that ift $t_{\text {count }}>t_{\text {table }}$, then refuse ${ }_{0}$ and receive, otherwise if $t_{\text {count }}$ $<\mathrm{t}_{\text {table }}$ then accept 0 and refuse.

From Table 1 it can be seen that the value of $t_{\text {count }}$ of Islamic bank income $(X)$ is -0.193 with a significant value of 0.848 , while the value of $t_{\text {table }}$ with $(\mathrm{df})=\mathrm{nk}(32-3=2)$ at $=0.05$, a value of 1.699 is obtained, meaning that it is greater than the degree of error of $5 \%(0.05)$. Then the decision to accept 0 and refuse ${ }_{1}$, which means partially Islamic bank income $(X)$ does not have a significant negative effect on Bank BRI's profitability (Y) or it can also be seen through the probability value.

\section{b. Effect of Conventional Bank Income (X) Against Bank Profitability (Y)}

Next variable value $t_{\text {count }}$ of Conventional Bank Income $(X)$ is 0.095 with a significant value of 0.924 , while the value of $t_{\text {table }}$ of 1.699 means that it is greater than the degree of error of $5 \%$ (0.05). Then the decision to accept 0 and refuse, which means partially conventional bank income (X) does not have a significant positive effect on Bank BRI's profitability. 


\section{c. Simultaneous Test (F Test)}

This test is carried out using a simultaneous significant test, namely the F test, to show whether the independent variable (independent) jointly have an influence on the dependent variable (dependent).

From Table 4.1 it can be seen that the value of ${ }_{\mathrm{i} g}$ of 0.030 with a significant value of 0.969 at the $95 \%$ confidence level. Whereas e obtained a value of 3.33 at $=0.05$. Therefore $\mathrm{i}_{\mathrm{g}}>_{\mathrm{e}}$ namely $0.030<3.33$ and a significant value of $0.96>0.05$. From the results of the $\mathrm{F}$ test, it means that 0 accept or reject, thus the income of Islamic banks and income of conventional banks together does not significantly affect the profitability of Bank BRI.

\section{CLOSING}

Based on the results of research conducted by the author through documentation and processed data using multiple linear regression, several conclusions can be drawn as follows:

1. The results found that the Islamic bank income variable $(\mathrm{X})$ does not significantly affect the profitability of Bank BRI (Y).

2. Conventional bank income variable (X) does not have a significant positive effect on Bank BRI's profitability.

3. Taken together, the variables of Islamic bank income and conventional bank income have no significant effect on the profitability of BRI Bank, and the magnitude of the influence of Islamic bank income and conventional bank income on BRI bank profitability is $0.06(6 \%)$ and the rest of $11-0.06=0.94(94 \%)$.

\section{REFERENCES}

Ahmad, R. (2011). Teaching Media in Djamarah, Syaiful Bahri and Aswan Zain. Learning Strategy Teach. Jakarta: Rineka Cipta.

Antonio, MS (2010). Islamic banking from theory to practice. Jakarta: Gema Insni Press.

Ekowati. (2012).Effect of Wadiah Savings Fund and Mudharabah Mutlaqah Investment Fund on State Islamic Commercial Bank Profit. Malang: Department of Accounting, State University of Malang.

Ema Rindawati. (2007)."Comparative Analysis of Islamic Banking Financial Performance with Conventional Banking." Jakarta: Indonesian Islamic University.

Ferdiansyah. (2005). Utilization of Chitosan from Shrimp Shells as a Support for Immobilization Protease Enzyme. Department of Agricultural Products Technology. Faculty of Fisheries and Marine Science. https://doi.org/Bogor Agricultural Institute

Ghozali, I. (2012). Multivariate Analysis Application With SPSS Program Edition I. Semarang: University Dipenogoro.

Jufridar, J., Ilham, R. N., \& Sinurat, M. (2021). Analisis Potensi dan Risiko Investasi pada Instrumen Keuangan dan Aset Digital Cryptocurrency di Indonesia. Jurnal EMT KITA, 5(1), 91-98.

Muhammad, R. (2016). Effect of Age diversity and Occupational Heterogeinety on financial bank common in Indonesia. Journal of STIE Indonesia Banking School. https://doi.org/Jurnal STIE Indonesia

No:15/DSN-MUI/IX/2000., FDSN (2000). LKS Business Profit Sharing Distribution.

Novita Wulandari. Maharani, K. (2010). Comparative Analysis. Islamic Banking Financial Performance With Conventional Banking. Journal of the Faculty of Economics. Veterans National Development University, 2. https://doi.org/Novita Wulandari. 2004, in Maharani, Kiki. 2010.Journal of the Faculty of Economics. Veterans National Development University

Qodriasari Indriani Laela. (2014). Analysis of the Effect of Mudharabah, Musyarakah, Murabahah, and Ijarah Lease Against the Profitability of Islamic Commercial Banks in Indonesia for the 
Period of 2011-2013. Journal of Business Administration, Faculty of Administrative Sciences, University of Muhammadiyah University, 1. https://doi.org/Jurnal of Business Administration, Faculty of Administrative Sciences, University of Muhammadiyah University

Sebatiningrum, NK (2006). "The effect of capital adequacy ratio (CAR), liquidity, and efficiency operations on the development of banking businesses listed on the JSE. Unnes Semarang Sanusi, Muhammad, 2009, The Power Of Alms, 2. https://doi.org/Pustaka Insan Madani

Sinurat, M., Ilham, R. N., \& Cen, C. C. (2021, February). Asetpedia. id as a Start-Up Based Technology Benchmarking Innovation for Beginning Companies in the North Sumatera Region. In International Conference on Strategic Issues of Economics, Business and, Education (ICoSIEBE 2020) (pp. 109-114). Atlantis Press.

Sugiyono. (2010). Educational Research Methods Quantitative, Qualitative and R\&D Approaches. Bandung: Alphabet.

Wibowo, US and E. (2013). The Effect of Working Capital on Income With Business Length As Moderating Variables (Survey of Market Traders Klithikan Notoharjo Surakarta). Economics And Entrepreneurship, 13(2).

Widarjono, A. (2013). Econometrics, Fourth Edition. Yogyakarta 
ANALYSIS OF THE EFFECT OF ISLAMIC BANK INCOME AND INCOME CONVENTIONAL BANKS AGAINST BANK PROFITABILITY

DOI: $10.54443 /$ ijerlas.v2i1.130 